\title{
Association between agronomic characters and hay quality of sweet potato branches
}

\author{
Valter C de Andrade Júnior' ${ }^{\mathbb{D}}$; Luan Mateus S Donato ${ }^{2 \mathbb{D}}$; Alcinei $M$ Azevedo ${ }^{2} \mathbb{D}$; Amanda G Guimarães ${ }^{3 \mathbb{D}}$; \\ Orlando G Brito ${ }^{1} \mathbb{D}$; Davi M Oliveira ${ }^{3} \mathbb{D}$; Antônio Julio Medina ${ }^{3} \mathbb{D}$; Lidiane R Silva ${ }^{3 \mathbb{D}}$
}

${ }^{1}$ Universidade Federal de Lavras (UFLA), Lavras-MG, Brasil; valter.andrade@ufla.com; orlandocefet@yahoo.com.br; ${ }^{2}$ Universidade Federal de Minas Gerais (UFMG), Montes Claros-MG, Brasil; luan_mateus_sd@hotmail.com; alcineimistico@hotmail.com; ${ }^{3}$ Universidade Federal dos Vales do Jequitinhonha e Mucuri (UFVJM), Diamantina-MG, Brasil; amandagguimaraes@yahoo.com.br; davi_martinsoliveira@hotmail. com; antoniojulio.medina@hotmail.com, lirodrigues27@hotmail.com

\begin{abstract}
From the perspective of the use of sweet potato branches for animal feed, there is a lack of information on the influence of this action on hay quality. Therefore, the objective was to study the association of sweet potato yield attributes with chemicalbromatological characteristics of hay. Ten sweet potato clones were evaluated, conducted in randomized blocks with five replications. Green and dry mass yield, dry mass content, leaf and stem ratio, total and commercial root yield, and chemical and bromatological characteristics of hay from the branches were determined. Phenotypic correlation and trial analysis between characteristics were estimated. Selection for the highest yield of roots and commercial roots may provide increased hay of crude protein, neutral detergent fiber and acid and total soluble sugars. However, selection for the highest root yield has a negative effect on the starch content of hay and deserves special attention from the breeder.
\end{abstract}

Keywords: Ipomoea batatas, animal feed, trial analysis.

\section{RESUMO}

Associação entre caracteres agronômicos e qualidade de feno de ramas de batata-doce

Sob perspectiva do uso das ramas de batata-doce para a alimentação animal, há carência de informações da influência desta ação sobre a qualidade do feno. Logo, objetivou-se estudar a associação dos atributos de produtividade da batata-doce com características químicas-bromatológicas do feno. Foram avaliados dez clones de batata-doce, conduzidos em blocos ao acaso com cinco repetições. Determinou-se as produtividades de massa verde e seca, teor de matéria seca e a relação folha e haste das ramas, a produtividade total e comercial de raízes, e, características químicobromatológicas dos fenos a partir das ramas. Estimou-se a correlação fenotípica e a análise de trilha entre as características. A seleção para a maior produtividade de ramas e de raízes comerciais pode proporcionar o aumento no feno da proteína bruta, fibra de detergente neutro e ácido e açúcares solúveis totais. Porém, a seleção para a maior produtividade de raízes tem efeito negativo no teor de amido do feno, merecendo atenção especial do melhorista.

Palavras-chave: Ipomoea batatas, alimentação animal, análise de trilha.

Received on November 27, 2018; accepted on August 14, 2019

$\mathrm{T}^{\mathrm{h}}$ he search for supplies for grazing animals in the dry season is constant, as there is usually a great shortage of pastures, causing animal mortality due to lack of food (Viana et al., 2011). This fact determines the demand by the producer of food alternatives in order to supply the low forage availability for ruminant animals thus establishing a nutritive efficiency for their growth and development (Ferreira et al., 2014).

Thus, sweet potato (Ipomoea batatas) may be an alternative because, despite being traditionally cultivated for the production of roots for human consumption, its branches have satisfactory characteristics for animal feed, because they are rich in sugars, vitamins and have high crude protein content, total digestive nutrients and digestibility (Pedrosa et al., 2015). Sweet potato is a tuberous vegetable with wide adaptation to different environments, characterized by its rusticity, low production cost and mainly cultivated by small producers (Andrade Junior et al., 2016).

Due to their high protein content, sweet potato branches can be fed to various animal species such as pigs and cattle (Veiga et al., 2009; Ly et al., 2010). Branches can be supplied to animals in fresh form, dried or preserved in silage (Andrade Junior et al., 2014; Pedrosa et al., 2015). However, one form of use in animal feed is the use of hay branches.

The haymaking technique is based on the principle of conservation of the forage nutritive value through rapid dehydration, in the face of paralysis of the respiratory activity of the plant 
and of microorganisms, baling and storage (Calixto Júnior et al., 2012). For good quality hay production it is necessary to take into account the use of plants with high nutritive value, easily dehydratable, which is related to cuticle thickness, stem diameter and length and leaf/stem ratio among others (Andrade et al., 2006).

This haying process has not been reported for the conservation of sweet potato branches, which indicates the need for research aimed at increasing the producer's alternatives for animal feed throughout the year. Thus, studies of cultivars with high yield of roots for human consumption and branches for animal feed become important in order to obtain information on both agronomic and hay quality characteristics. Therefore, the objective of the present research was to study the relationships between the agronomic characteristics of sweet potatoes for the municipality of Diamantina-MG and the qualitative characteristics of hay.

\section{MATERIAL AND METHODS}

The work was conducted in the Olericulture sector of the Department of Agronomy of the Universidade Federal dos Vales do Jequitinhonha e Mucuri (UFVJM), in DiamantinaMG (18'12'1',S, 4334'20'”W, 1,400 $\mathrm{m}$ altitude), from September 2015 to April 2016. The soil of the experimental area is classified as a typical Arctic Quartzarenic Neossol (Embrapa, 2013).

The experimental design was a randomized complete block with 10 treatments (genotypes) and five replications, totaling 50 experimental plots of two rows, $4.5 \mathrm{~m}$ each. Spacing was $1.0 \mathrm{~m}$ between rows and $0.30 \mathrm{~m}$ between plants. The evaluated clones (UFVJM-07, UFVJM-10, UFVJM-13, UFVJM-15, UFVJM-23, UFVJM-35, UFVJM-37, UFVJM-45, UFVJM-46, UFVJM-54) belong to the sweet potato germplasm bank of UFVJM, and presented potential for use in animal feed, mainly in the form of silage (Andrade Júnior et al., 2016). The germplasm bank is formed by specimens from various Brazilian regions, including the Jequitinhonha Valley.

Planting fertilization consisted of $10 \mathrm{t} \mathrm{ha}^{-1}$ organic compost and $30 \mathrm{~kg}$ $\mathrm{ha}^{-1}$ nitrogen. Selected and standardized branches with eight knots were planted, burying from 3 to 4 knots. At 30 days after planting the branches, $30 \mathrm{~kg} \mathrm{ha}^{-1}$ nitrogen was applied as ammonium sulfate. Planting, mulching, irrigation and weeding were made as recommended for the crop (Filgueira, 2008).

\section{Characteristics evaluated}

Branches and roots were harvested 150 days after planting, when the roots were developed. The analyzed characteristics were: a) green mass yield of branches (BGMY) ( $\left.\mathrm{t} \mathrm{ha}^{-1}\right)$ determined by weighing the harvested branches; b) dry mass content of the branches (DMB), quantified by samples of the newly harvested branches. Homogeneous samples of $500 \mathrm{~g}$ in each experimental unit were placed in paper bags and kept in an oven with forced ventilation at $60^{\circ} \mathrm{C}$, until reaching constant mass; c) branch dry mass yield (BDMY) ( $\left.\mathrm{t} \mathrm{ha}^{-1}\right)$, obtained by the product between green mass yield and root dry mass content; d) leaf and stem ratio (LS), determined by the ratio of leaf dry mass to stem dry mass, of a representative sample of branches, approximately $500 \mathrm{~g}$ of fresh material, separated into leaf and stem fractions that were weighed and placed into an oven with forced ventilation at $60^{\circ} \mathrm{C}$ until constant weight; e) total root yield (TRY) ( $\mathrm{t} \mathrm{ha} \mathrm{h}^{-1}$ ), obtained by weighing the roots; f) commercial root yield (CRY) ( $\left.\mathrm{t} \mathrm{ha}^{-1}\right)$, selection of roots with mass between 100 and 800 grams, without cracking, deformed, greenish, perforated or with veins.

For hay production, the sweet potato branches were crushed into pieces, approximately 3 to $5 \mathrm{~cm}$, later taken to the greenhouse and distributed to the experimental plots over plastic canvas in uniform layers of 2 to $3 \mathrm{~cm}$ for drying until reducing the moisture content of fresh branches to less than $18 \%$, during about four days.

After obtaining the hay, $500 \mathrm{~g}$ of material were collected in each sample unit, taken to the oven with forced air ventilation and kept at $60^{\circ} \mathrm{C}$ for drying until constant mass. The material was then sent for chemical-bromatological analysis to obtain 1) neutral detergent fiber (NDF); 2) acid detergent fiber (ADF) and 3) lignin (LIG) according to Detmann et al. (2012); 4) crude protein (CP) obtained by the LECO ${ }^{8}$ CHNS / $\mathrm{O}$ elemental analyzer and the value multiplied by the conversion factor 6.25 ; 5) total soluble sugars (TSS) and 6) starch, through Mc Cready et al. (1950) with values expressed as percentage of dry mass.

\section{Statistical analysis}

Statistical analyzes were performed using Genes software (Cruz, 2013). A correlation matrix between the characteristics was estimated, which was tested for multicollinearity by the matrix condition number (NC) proposed by Montgomery et al. (2012). To unfold the correlation into direct and indirect effects, we resorted to trial analysis. When multicollinearity $(\mathrm{NC}>1000)$ was identified, the crest or communal trial analysis methodology was used (Cruz et al., 2012). The dependent (basic) variables considered were the characteristics associated with hay quality: CP, ADF, NDF and starch. The explanatory variables were the characteristics that presented significant phenotypic correlation with the basic variable according to the $t$ test $(\mathrm{p} \leq 0.05)$.

\section{RESULTS AND DISCUSSION}

\section{Phenotypic correlations between agronomic characteristics and sweet potato hay quality}

Estimates of significant phenotypic correlations ranged from -0.37 (total soluble sugars and leaf-stem ratio) to 0.97 (green mass yield and dry mass yield) (Figure 1). In general, phenotypic correlations were of low magnitude and not significant. This indicates that selection for one characteristic tends not to affect the others.

Estimates of positive and significant phenotypic correlation between characters show that in practice, it is necessary to evaluate only the most easily determined character. This means that selection will be performed indirectly on the other associated character, thus reducing the time spent 
on evaluations, which may or may not benefit from the same causes of variation (Cruz et al., 2012).

Thus, significance was observed between the characteristics: branches green mass yield (BGMY) and branch dry mass yield (BDMY) (0.97); total root yield (TRY) and commercial root yield (CRY) (0.95); leaf and stem ratio (LS) with TRY (0.42) and CRY (0.42), and crude protein (PB) with LS (0.69), TRY (0.51) and CRY (0.46); neutral detergent fiber (NDF) with BDMY (0.33), CRY (0.54) and dry mass content of the branches (DMB) (0.54); acid detergent fiber (ADF) with CRY (0.46), DMB (0.74) and NDF (0.59); lignin (LIG) and NDF (0.47); total soluble sugars (TSS) with BGMY (0.57) and BDMY (0.55) (Figure 1).

The use of sweet potato branches in animal feed can be either fresh or preserved and dried (silage or hay) (Andrade Junior et al., 2014). There was a high and positive correlation (0.97) between the related productivities for the different ways of animal consumption, branches green mass yield (BGMY) and branch dry mass yield (BDMY) (Figure 1). If you select indirectly for the BGMY characteristic, you will benefit from BDMY.

The significant association of the leaf-stem ratio (LS) characteristic with TRY (0.42) and CRY (0.42) (Figure 1) shows that the evaluation of the aerial part will select satisfactory yields for sweet potato roots. The occurrence of significant correlation between LS and crude protein (0.69) (Figure 1) presents one of the qualities of hay, because higher protein levels are desirable in forage in order to satisfy the nutritional needs of animals. This result corroborates with the findings of Wilson \& Kennedy (1996), who reported that a high leaf and stem ratio may be indicative of high protein content, digestibility and animal consumption. Similarly, CP correlated with TRY (0.51) and CRY (0.46) (Figure 1) validating selection reasoning in the same way as LS.

The nutritional value of plants is characterized by their chemicalbromatological composition and the interaction of this composition with animal consumption. Thus, dry mass content of the branches (DMB) is the portion of the food that contains all nutrients such as energy sources (sugars), fiber, minerals and protein (Van Soest, 1994). Thus, the higher the dry mass content, the higher will be the contents of the essential elements in animal nutrition, increasing their feed efficiency.

There was a significant correlation between shoot dry mass content of the branches (DMB) with acid detergent fiber (ADF) (0.74) and neutral detergent fiber (NDF) (0.54) (Figure 1). The first association may be due to the average DMB (above 90\%) and ADF ( $40 \%$ limit) content of the sweet potato genotypes obtained in the present work (Donato, 2016), considered satisfactory and adequate for better conservation and voluntary consumption of MS by animals (Simon et al., 2009). Estimates between NDF and ADF (0.59) are desirable, since they make up the fibrous fraction of the food, and the lower the ADF and NDF contents, the higher the digestibility and consumption of hay, respectively. High fibrous fraction values are known to impair the action of microorganisms on the digestible tract of animals (Van Soest, 1994).

Identifying sweet potato genotypes for human consumption should prioritize both high yields and good quality of commercial roots. Thus, the complementation of these characteristics to the good quality of the branches, aiming its use in the form of hay for animal feed, is of fundamental importance for the full utilization of

Table 1. Estimation of coefficient of determination $\left(\mathrm{R}^{2}\right)$, effect of residual variable (Pe), number of conditions (NC), highest variance inflation factor (VIF) and k-value for crest regression in the track analysis for four basic variables. Diamantina, UFVJM, 2015/2016.

\begin{tabular}{lcccc}
\hline \multirow{2}{*}{ Parameters } & \multicolumn{4}{c}{ Basic variables } \\
\cline { 2 - 5 } & CP & ADF & NDF & Starch \\
\hline $\mathrm{k}$ & 0.04 & 0.00 & 0.00 & 0.006 \\
$\mathrm{R}^{2}$ & 0.67 & 0.69 & 0.67 & 0.780 \\
$\mathrm{Pe}$ & 0.57 & 0.56 & 0.57 & 0.470 \\
$\mathrm{NC}$ & 46.33 & 6.20 & 13.92 & 42.820 \\
$\mathrm{VIF}_{\text {highest }}$ & 9.91 & 2.08 & 0.42 & 9.860 \\
\hline $\mathrm{CP}$
\end{tabular}

$\mathrm{CP}=$ crude protein; $\mathrm{NDF}=$ neutral detergent fiber; $\mathrm{ADF}=$ acid detergent fiber.

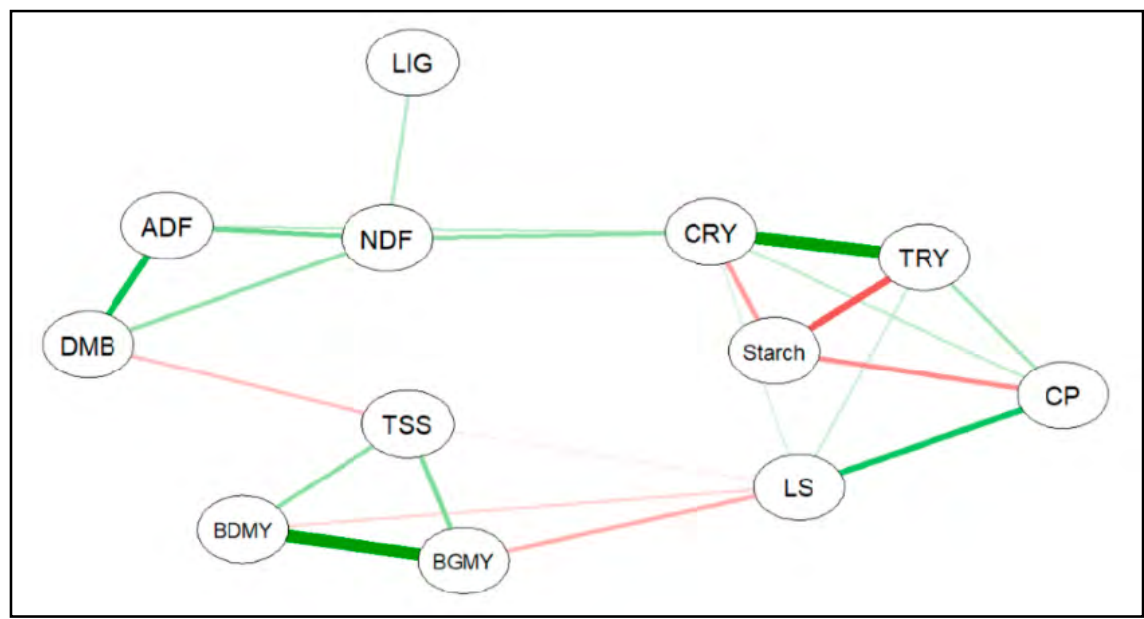

Figure 1. Graphical representation of significant $(\mathrm{p} \leq 0.05)$ positive (green) and negative (red) t-test correlations between agronomic and chemical characters in sweet potato hay. BGMY= branch green mass yield; $\mathrm{BDMY}=$ branch dry mass yield; $\mathrm{LS}=$ leaf/stem ratio; $\mathrm{TRY}=$ total root yield; $\mathrm{CRY}=$ commercial root yield; $\mathrm{DMB}=$ dry matter content of the branches; $\mathrm{CP}=$ crude protein; $\mathrm{NDF}=$ neutral detergent fiber; $\mathrm{ADF}=$ acid detergent fiber; $\mathrm{LIG}=$ lignin; $\mathrm{TSS}=$ total soluble sugars. Diamantina, UFVJM, 2015/2016. 
the plant. These associations can be observed with the two characteristics for hay quality, ADF and NDF, which resulted in significant correlations with CRP, 0.46 and 0.54 , respectively (Figure 1).

The analysis of lignin is extremely important to verify the degradation of forages and thus the nutritional utilization of animal feed. The amount of lignin present in food is a critical factor regarding digestibility, as it is associated with fibrous carbohydrates in plant cell walls, thus limiting cellulose and hemicellulose digestibility (Norton, 1982). Thus, indirect selection of the trait LIG or NDF (significant correlation 0.47) (Figure 1) may be able to provide higher consumption by the animal, since low levels of these two characteristics are desirable.

Positive estimates between the yield characteristics of green or dry mass of sweet potato branches with chemical-bromatological characteristics are desirable for better use of plants in the field and also for animal feed. Thus, indirect selection of BDMY may lead to NDF quality and total soluble sugars (TSS), which presented significant coefficients of 0.33 and 0.55 respectively (Figure 1). TSS are of great importance as they are concentrated sources of rapidly degrading energy supplied to microorganisms in ruminant animals (Medeiros \& Marino, 2015). The relationship between TSS and BGMY was also found (0.57) (Figure 1), showing that the selection of high BGMY values will lead to higher levels of TSS in sweet potato hay.

On the other hand, when the phenotypic correlation is negatively significant, one character is favored

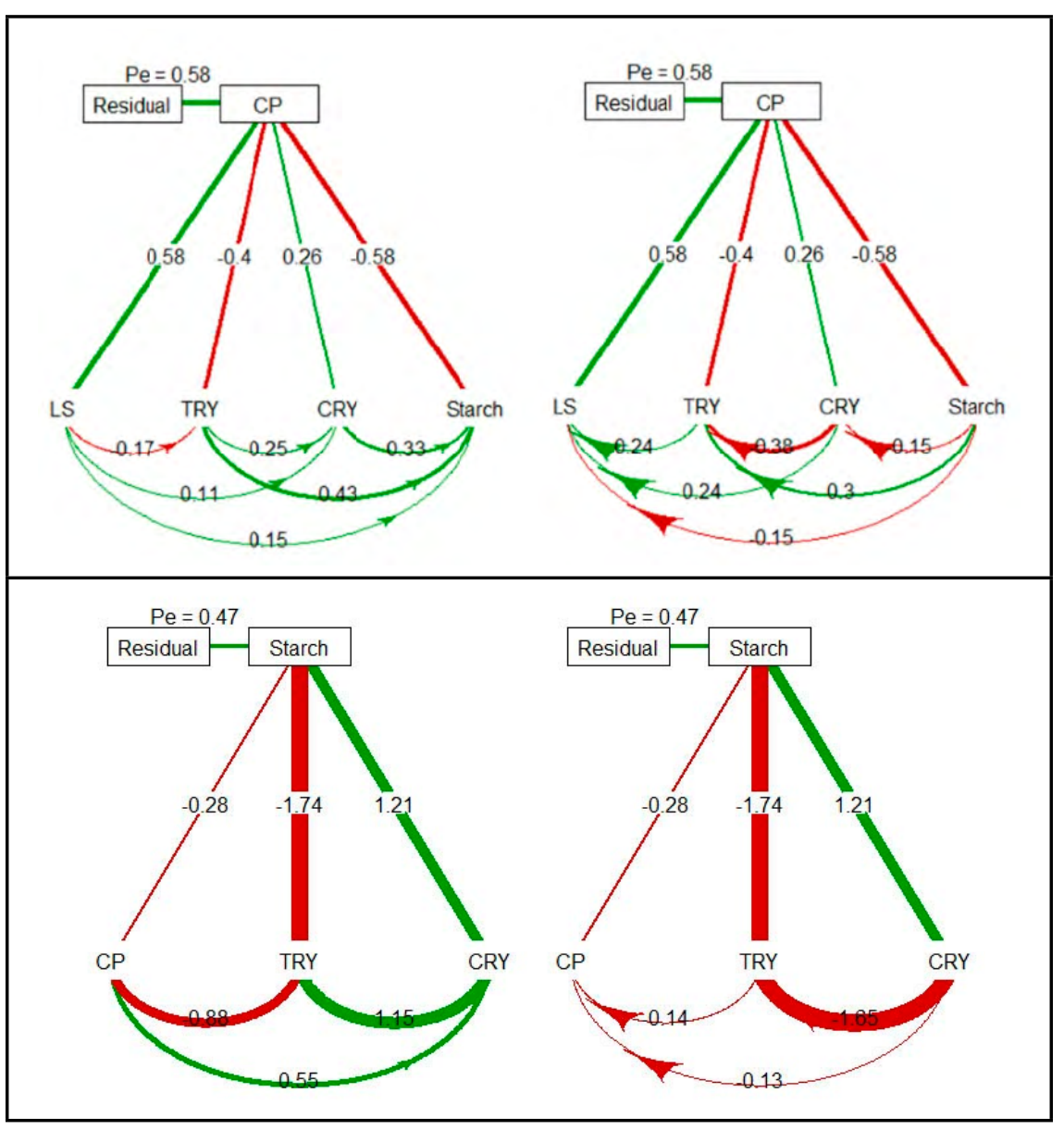

Figure 2. Unfolding of phenotypic correlations in direct (straight line) and indirect (arrow line) effects components in sweet potato hay involving a) dependent main variable (CP) and explanatory independent variables (LS, TRY, CRY, starch), b) dependent main variable (starch) and the explanatory independent variables (CP, TRY, CRY). Diamantina, UFVJM, 2015/2016. over the other, which may provide undesirable gains for characteristics, as found in: LS with BGMY (-0.52), $(-0.44)$ and TSS (-0.37); TSS and DMB $(-0.48)$; starch with TRY (-0.74), CRY (-0.56) and CP (-0.61) (Figure 1). Thus, it becomes difficult to determine which characteristics measure the relative importance of agronomic characters with the quality of sweet potato hay. Therefore, an alternative is to adopt another statistic, the trial analysis, to quantify the direct and indirect effects on the (basic) characteristic of interest (Cruz et al., 2012).

Contribution of components for direct and indirect effects between yield characteristics and quality of sweet potato hay

Only those characteristics that were significant with the basic variables [crude protein (CP), neutral detergent fiber (NDF) and acid and starch] were considered. The phenotypic correlation matrix between the characters resulted in weak multicollinearity $(\mathrm{NC}<100)$ when considering ADF and NDF as basic variables (Table 1). When basing $\mathrm{CP}$ and starch as basic variables, it was necessary to use crest trial analysis. The coefficients of determination were moderately satisfactory for the trial analyzes, with estimates over $67 \%$ indicating that there is a direct effect of the explanatory variables (Table 1).

The chemical-bromatological evaluations of hay are important because in animal feed the nutritional state of the animal depends mainly on this composition (Van Soest, 1994). When the basic variable was crude protein (CP), the leaf-stem ratio (LS) (0.58) resulted in the largest direct effect on $\mathrm{CP}$ because it was equal to the residual effect value (0.58) (Figure 2a), showing that this variable is the main determinant of $\mathrm{CP}$ variation providing greater impact in terms of selection gain. For total root yield (TRY) and starch it was observed in the unfavorable direction, -0.4 and -0.58 respectively (Figure $2 \mathrm{a}$ ). This indicates the absence of cause and effect, ie, TRY and starch characteristics are not the main determinants of changes in the basic variable $C P$.

The CP content is a good measure of hay quality. It allows higher 


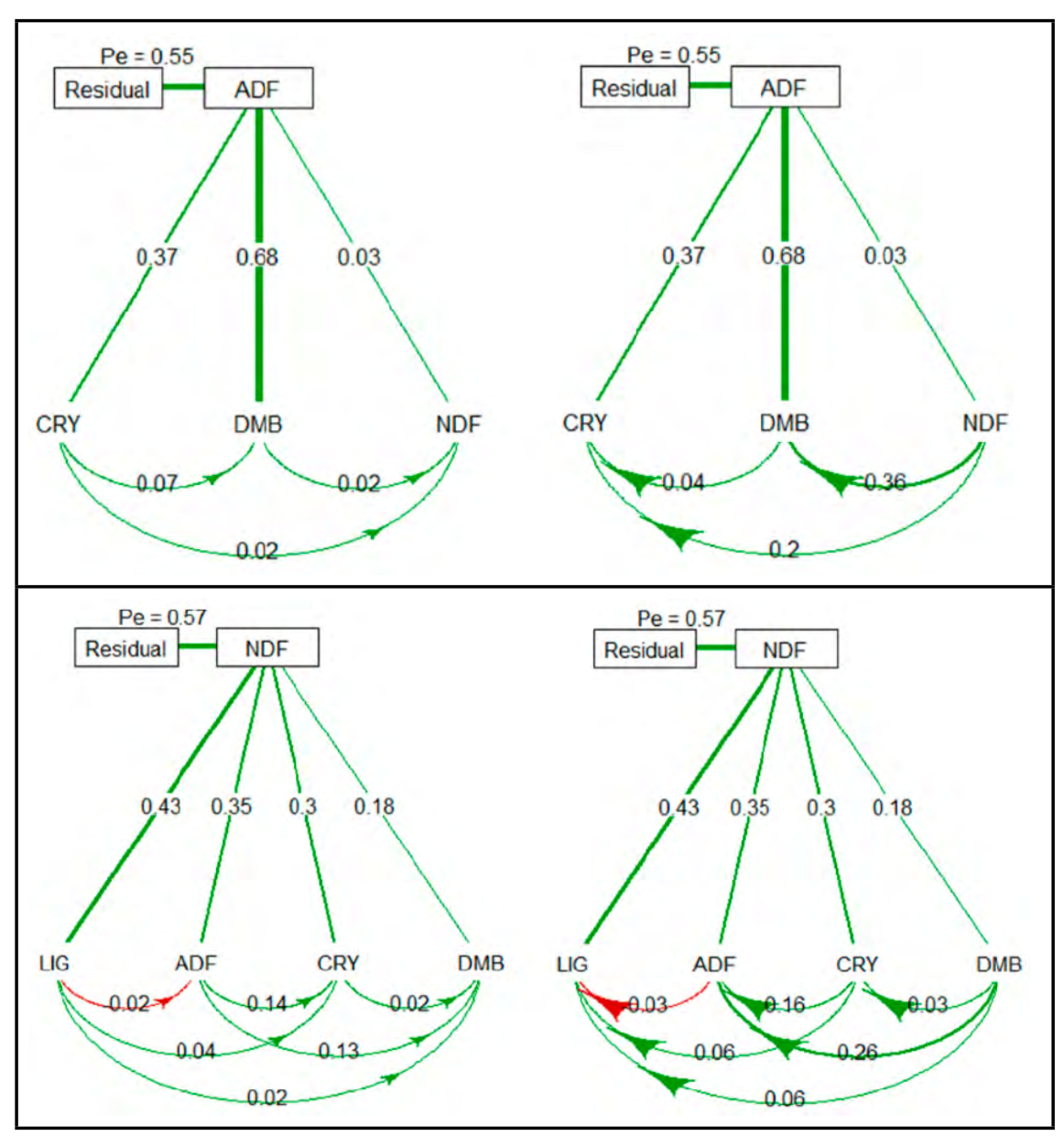

Figure 3. Unfolding of phenotypic correlations in direct effects (straight lines) and indirect effects (arrow lines) components in sweet potato hay, involving: a) dependent main variable (ADF) and explanatory independent variables (CRY, DMB, NDF), b) dependent main variable (NDF) and the explanatory independent variables (LIG, ADF, CRY, DMB). Diamantina, UFVJM, 2015/2016.

consumption of dry mass by animals, as the rumen nitrogen deficiency results in less growth of the rumen microbiota. This deficiency does not meet nutritional requirements, with decreased cell wall digestion and consumption (Wilson \& Kennedy, 1996). Thus, crude protein is the most required ingredient after energy for the development of ruminant metabolic functions (Paiva et al., 2013).

The presence of starch in the food is important because it plays a significant contribution in the rumen fermentation products. This improves the quality of the food, since the greater inclusion of concentrate in the diet tends to decrease ruminal $\mathrm{pH}$ and rumination and, consequently, buffering through saliva (Van Soest, 1994). However, sweet potato hay starch as the basic variable showed only a direct effect the dry mass characteristic, it is also selected directly for ADF.

Although the characteristics LIG, ADF, CRY and DMB were positively correlated with the basic variable NDF, they did not determine direct effect with it. This was due to the fact that these explanatory variables presented values below the residual effect $(0.57)$ (Figure 3b). This shows that these characteristics had small indirect effects among them, being essential to predict these phenotypic correlations with NDF.

Differences between the direct and indirect effects of hay agronomic and chemical-bromatological characteristics may be due to the non-commercial genetic materials tested for the traits of interest. Therefore, results of different performances show the need for further research of these genotypes to achieve higher yields of roots, twigs and quality of sweet potato hay according to their suitability.

From the results presented, it is important to identify an association of sweet potato yield attributes with hay chemical characteristics. Thus, the association of highly correlated variables with the basic variable of greatest direct effect in favor of selection is preferable for the correlated response through indirect selection to be efficient. Therefore, the characteristics that positively correlated were CRY with $\mathrm{CP}, \mathrm{NDF}, \mathrm{ADF}$; and the BDMY of NDF and TSS branches. As for the significantly positive direct effects: 1 ) in the basic variable $\mathrm{PB}$ with the variable LS; 2) ADF as basic variable as DMB content; and 3) basic variable starch CRY variable. However, when direct positive as well as high and negative indirect effects are observed, indirect selection may not provide satisfactory gains, as in the basic NDF variable and other characteristics, and in the starch basic variable with CP and TRY.

Thus, we concluded that selection for higher yield of roots and commercial roots can provide increased crude protein, neutral and acid detergent fiber, and total soluble sugars in the hay. Selection for the highest root yield has a negative effect on the starch content of hay, deserving special attention from the breeder. 


\section{ACKNOWLEDGMENTS}

The Minas Gerais State Research Support Foundation (FAPEMIG), and the National Council for Scientific and Technological Development (CNPq) for the scholarships and financial support granted. This work was carried out with the support of the Higher Education Personnel Improvement Coordination Brazil (CAPES) - Financing Code 001.

\section{REFERENCES}

ANDRADE JÚNIOR, VC; GOMES, JAA; OLIVEIRA, CM; AZEVEDO, AM; FERNANDES, JSC; GOMES, LAA; MALUF, WR. 2016. Resistência de clones de batata doce a Meloidogyne javanica. Horticultura Brasileira 34: 130-136.

ANDRADE JÚNIOR, VC; PEREIRA, RC; DORNAS, MFS; RIBEIRO, KG; VALADARES, NR; SANTOS, AA; CASTRO, BMC. 2014. Produção de silagem, composição bromatológica e capacidade fermentativa de ramas de batata-doce emurchecidas. Horticultura Brasileira 32: 91-97.

ANDRADE, MVM; SILVA, DS; QUEIROZ FILHO, JL; PINTO, MSC. 2006. Desidratação de cultivares de alfafa (Medicago sativa) durante o processo de fenação. Archivos de Zootecnia 55: 385-388.

CALIXTO JUNIOR, M; JOBIM, CC; CECATO, U; SANTOS, GT; BUMBIERIS JUNIOR, VH. 2012. Curva de desidratação e composição químico-bromatológica do feno de gramaestrela (Cynodonnlem fuensis Vanderyst) em função do teor de umidade no enfardamento. Semina: Ciências Agrárias 33: 2411-2422,

CRUZ, CD. 2013. Genes: a software package for analysis in experimental statistics and quantitative genetics. Acta Scientiarum Agronomy 35: 271-276.

CRUZ, CD; REGAZZI, AJ; CARNEIRO, PCS.
2012. Modelos biométricos aplicados ao melhoramento genético. Viçosa, BR: UFV. $514 \mathrm{p}$.

DETMANN, E; SOUZA, MA; VALADARES FILHO, SC; QUEIROZ, AC; BERCHIELLI, TT; SALIBA, EOS; CABRAL, LS; PINA, DS; LADEIRA, MM; AZEVEDO, JAG. 2012. Métodos para análise de alimentos. Visconde do Rio Branco, BR: INCT-Ciência Animal. 214p.

DONATO, LMS. 2016.Uso de ramas de batatadoce para produção de feno. Diamantina, UFVJM. 42p (Dissertação de Mestrado)

EMBRAPA. 2013. EMPRESA BRASILEIRA DE PESQUISA AGROPECUÁRIA. Sistema Brasileiro de Classificação de Solos. $3^{\circ}$ ed. Brasília, BR: Embrapa. 353p.

FERREIRA, DJ; ZANINE, AM; LANA, RP; RIBEIRO, MD; ALVES, GR; MANTOVANI, HC. 2014. Chemical composition and nutrient degradability in elephant grass silage inoculated with Streptococcus bovisisolated from the rumen. Anais da Academia Brasileira de Ciências 86: 465-474.

FILGUEIRA, FAR. 2008. Novo manual de olericultura: Agrotecnologia moderna na produção e comercialização de hortaliças. Viçosa, BR: UFV. 402p.

LY, NTH; NGOAN, LD; VERSTEGEN, MWA; HENDRIKS, WH. 2010. Ensiled and dry cassava leaves, and sweet potato vines as a protein source in diets for growing vietnamese large white $\times$ mongcai pigs. AsianAustralasian Journal of Animal Sciences 23: 1205-1212.

MC CREADY, RM; GUGGOLZ, J; SILVIERA, V; OWENS, HS. 1950.Determination of starch and amylose in vegetables. Application to peas. Analytical Chemistry 22: 1156-1158.

MEDEIROS, SR; MARINO, CL. 2015. Carboidratos na nutrição de gado de corte. In: MEDEIROS, SR; GOMES, RC; BUNGENSTAB, DJ. Nutrição de bovinos de corte: fundamentos e aplicações. Brasília, BR: Embrapa. p. 45-62.

MONTGOMERY, DC; PECK, EA; VINING, GG. 2012. Introduction to linear regression analysis. New York: John Wiley. 672p.
NORTON, BW. 1982. Differences between species in forage quality. In: HACKER, J.B. (Ed.). Nutritional limits to animal production from pastures. Farnham Royal, UK: Common wealth Agricultural Bureaux, p. 89-110.

PAIVA, VR; LANA, RP; OLIVEIRA, AS; LEÃO, MI; TEIXEIRA, RMA. 2013. Teores proteicos em dietas para vacas Holandesas leiteiras em confinamento. Arquivo Brasileiro de Medicina Veterinária e Zootecnia 65: 1183-1191.

PEDROSA, CE; ANDRADE JÚNIOR, VC; PEREIRA, RC; DORNAS, MFS; AZEVEDO, AM; FERREIRA, MAM. 2015. Yield and quality of wilted sweet potato vine sand its silages. Horticultura Brasileira 33: 283-289.

SILVA, MJS; JOBIM, CC; NASCIMENTO, WG; FERREIRA, GDG; SILVA, MS; TRÊS, TT. 2013. Estimativa de produção e valor nutritivo do feno de estilosantes cv. Campo Grande. Semina: Ciências Agrárias 34: 1363-1380.

SIMON, JE; JUNIOR, L; FERREIRA, GDG; SANTOS, N; NAHUM, BDS; MONTEIRO, EMM.2009. Consumo e digestibilidade de silagem de sorgo como alternativa para alimentação suplementar de ruminantes na Amazônia Oriental. Amazônia: Ciência \& Desenvolvimento 4: 103-119.

VAN SOEST, PJ. 1994. Nutritional ecology of the ruminant. Ithaca, USA: Cornell University Press. 446p.

VEIGA, IRFM; GONÇALVES, LC; LOBATO, FCL; FARIA JUNIOR, WG. Batata-doce na alimentação de gado de leite. Belo Horizonte, BR: FEPMVZ, 2009. 568p.

VIANA, DJS; ANDRADE JUNIOR, VC; RIBEIRO, KG; PINTO, NAVD; NEIVA, IP; FIGUEIREDO, JA; LEMOS, VT; PEDROSA, CE; AZEVEDO, AM. 2011. Potencial de silagens de ramas de batata-doce para alimentação animal. Ciência Rural 41: 1466-1471.

WILSON, JR; KENNEDY, PM. 1996. Plant and animal constraints to voluntary feed intake associated with fibre characteristics and particle breakdown and passage in ruminants. Australian Journal of Agricultural Research 47: 199-225. 